\title{
Supraglottic Cancer pT1 TNM Finding v8
}

National Cancer Institute

\section{Source}

National Cancer Institute. Supraglottic Cancer pT1 TNM Finding v8. NCI Thesaurus. Code C133102.

Supraglottic cancer with tumor limited to one subsite of suprag lottis with normal vocal cord mobility. (from AJCC 8th Ed.) 